\title{
Comparative Study between Cholecystectomy in Sickle Cell Patients and Non-Sickle Cell Patients
}

\author{
L. Soumare ${ }^{\text {* }}$, O. Sacko1, S. Diallo², M. Camara1, S. Koumare'1, M. Sissoko1, G. Soumare ${ }^{3}$, S. Keita1, \\ A. Camara' ${ }^{1}$ M. Diallo ${ }^{2}$, B. A. Toure ${ }^{4}$, M. Kanta ${ }^{4}$, A. S. Dembele ${ }^{5}$, A. Koita ${ }^{1}$, Z. Z. Sanogo ${ }^{1}$ \\ ${ }^{1}$ Department of Surgery A of CHU POINT G, Bamako, Mali \\ ${ }^{2}$ Department of Surgery B of CHU POINT G, Bamako, Mali \\ ${ }^{3}$ Department of Gastro Enterology of CHU Point G, Bamako, Mali \\ ${ }^{4}$ Center for Research and Control of Sickle Cell Disease, Bamako, Mali \\ ${ }^{5}$ Department of Anesthesiology-Reanimation of CHU POINT G, Bamako, Mali \\ Email: ${ }^{*}$ rsoumare@gmail.com
}

How to cite this paper: Soumare, L., Sacko, O., Diallo, S., Camara, M., Koumare, S., Sissoko, M., Soumare, G., Keita, S., Camara, A., Diallo, M., Toure, B.A., Kanta, M., Dembele, A.S., Koita, A. and Sanogo, Z.Z. (2019) Comparative Study between Cholecystectomy in Sickle Cell Patients and Non-Sickle Cell Patients. Surgical Science, 10, 303-309.

https://doi.org/10.4236/ss.2019.109033

Received: August 2, 2019

Accepted: September 15, 2019

Published: September 18, 2019

Copyright $\odot 2019$ by author(s) and Scientific Research Publishing Inc. This work is licensed under the Creative Commons Attribution International License (CC BY 4.0).

http://creativecommons.org/licenses/by/4.0/ (c) () Open Access

\begin{abstract}
Introduction: Laparoscopic cholecystectomy is the gold standard in the treatment of gallstones and lithiasis cholecystitis. It reduces post-operative complications especially in sickle cell patients. Aim: The aim of this work was to compare the results of laparoscopic cholecystectomy in sickle cell and non-sickle cell patients. Methods: Sixty-six patients including 25 sickle cell patients and 41 non-sickle cell patients were identified from March 2013 to November 2014 (20 months). The $\chi^{2}$ test was used for comparisons. Values of $\mathrm{p}<0.05$ were used for a statistically significant difference threshold. Results: The mean age was 25.76 years for the sickle cell group and 45.61 years for the non-sickle cell group $(\mathrm{p}=0.00008)$. There were $14 / 25$ female patients in the sickle cell group and 28/41 in the non-sickle cell group. In per op, the diagnosis of acute cholecystitis was retained for $4 / 25$ sickle cell patients and for $10 / 41$ non-sickle cell patients. Diagnoses such as pyocholecyst ( 2 cases), porcelain vesicle ( 2 cases), hydrocholecyst ( 2 cases) were found in the group of non-sickle cell patients. Operative difficulties such as tight perivicular adhesions were encountered 9/25 times in the sickle cell group and 11/41 times in the non-sickle cell group. The average overall operative time was $55 \mathrm{~min}$. There was no statistically significant difference between the different groups in mean operative time, occurrence of postoperative complication and average length of hospital stay. The mortality is not statistically different according to the group of patients. Conclusion: There is no significant difference between the cholecystectomy performed in sickle cell patients and that performed in non-sickle cell patients. The multidisciplinary perioperative man-
\end{abstract}


agement of sickle cell patients reduces the risk of complications arising from this pathology.

\section{Keywords}

Comparison, Cholecystectomy, Sickle Cell, Non-Sickle Cell

\section{Introduction}

Disease of the black race, sickle cell disease is one of the most common genetic diseases in our context. In Mali, the prevalence rate of sickle cell disease varies from $12 \%$ to $15 \%$ [1]. It is an autosomal recessive inherited disease, characterized by the presence of abnormal hemoglobin (hemoglobin S). It is responsible for structural and conformational changes of red blood cells and therefore major rheological disorders in the microcirculation [2]. Chronic hemolysis and hyper-bilirubinemia promote the formation of gallstones [2]. Vesicular lithiasis is therefore frequent during sickle cell disease ( $15 \%$ to $30 \%$ before age 20 and 50 to $60 \%$ after) [3]. Laparoscopic cholecystectomy is the gold standard in the treatment of gallstones and lithiasis cholecystitis. It reduces perioperative complications especially in sickle cell patients [4].

We did not find any studies comparing cholecystectomy in sickle cell and non-sickle cell patients in the literature.

The purpose of this study was to compare the cholecystectomy and its after-effects in sickle cell and non-sickle cell patients.

\section{Patients and Method}

This was a prospective study that took place over a period of 20 months, from March 2013 to November 2014. This study was conducted in the Surgery Department "A" of the Point G CHU in Bamako in Mali. It involved 66 patients with vesicular lithiasis. All sickle cell and non-sickle cell patients who underwent laparoscopic cholecystectomy were included in the study. A pre-established survey sheet was filled in each time a patient consulted for gallbladder stones. Patients were recruited after receiving a clear explanation of the study and with their informed consent. All those who have had a cholecystectomy, who have agreed to participate in the study and have gave their consent have been selected. The variables compared were year, ASA score, vesicular pathology involved, surgical technique, preoperative (hospital accident and mortality). The data was entered on the Microsoft Excel software and analyzed with the Epi InfoTM 7 software. The $\mathrm{KHI}^{2}$ test was used for comparisons. Values of $\mathrm{p}<0.05$ were used for a statistically significant difference threshold. The informed consent of each patient was obtained during a preoperative consultation. They were told about the course of the procedure, its advantages over conventional surgery, its possible complications and laparotomy conversions. The material used is the one 
commonly used. We did not have any device that allowed us to perform intraoperative cholangiography. All patients underwent general anesthesia with orbital tracheal intubation and curarization. The patients were all examined in consultation and programmed after the agreement of the anesthetists with or without particular recommendations. The follow-up of sickle cell patients was carried out by the doctors of the Anesthesia-Resuscitation Department, the Center for Research and Control of Sickle Cell Disease (CRLD) and the Surgical Service "A". A preoperative assessment was performed in all patients included in the study. Homozygous sickle cell patients were all transfused 24 hours before the operation. The transfusion took place at the CRLD before hospitalization in the surgical ward. Some non-sickle cell patients with cholecystitis were hospitalized at most 15 days before the operation. Their preoperative management consisted in cooling the cholecystitis by a bi antibiotherapy and an analgesic. Intraoperative management was mainly provided by anesthesiologists and surgeons. Peroperatively, each time the vesicle had a thin wall, the diagnosis of simple vesicular lithiasis was made. That of cholecystitis was placed in front of a thick-walled vesicle with or without adhesions. Intraoperative cholangiography and choledocoscopy are not available in Mali. For this reason, the search for calculations of the main bile duct has not been performed in intraoperative patients. Postoperatively, for sickle cell patients, emphasis was placed on analgesia, hydration, respiratory physiotherapy and oxygen therapy. This particular management made it possible to avoid the main postoperative complications that may occur in sickle cell patients (acute thoracic syndrome, vaso-occlusive seizures, haemolytic seizures or priapism). The overall duration of hospitalization was calculated from the admission ( 24 hours before the intervention) to the exit of the patient. The duration of intervention was calculated from the incision to the dressing. The duration of anesthesia was calculated from induction to awakening of the patient.

\section{Result}

Sixty-six patients were identified, including 25 sickle cell patients and 41 non-sickle cell patients in 20 months. Laparoscopic cholecystectomy accounted for $32.8 \%$ of the service's laparoscopic surgery activity. The age groups of each group are compared in Table 1 . The overall average age was 38.09 years with extremes of 13 years and 73 years. There were 14 female patients and 11 male patients in the sickle cell group and 28 female patients and 13 male patients in the non-sickle cell group. All sickle cell patients were rated ASA II while 22 non-sickle cell patients were rated ASA I and 19 ASA II. Perioperatively the diagnosis of acute cholecystitis was retained for 4 sickle cell patients and that of simple vesicular lithiasis for 21 sickle cell patients. Various diagnoses have been reported in non-sickle cell patients: acute cholecystitis $(n=10)$, simple vesicular lithiasis $(n=20)$, pyocholecyst $(n=2)$, porcelain vesicle $(n=2)$, hydrocholecyst $(n=5)$, vesicular gangrene $(n=1)$ and vesicular empyema $(n=1)$. The 
Table 1. Sickle cell status and age group.

\begin{tabular}{cccc}
\hline \multirow{2}{*}{ Age (year) } & \multicolumn{3}{c}{ Sickle cell status } \\
\cline { 2 - 4 } & Yes & No & Total \\
\hline$[0-20]$ & $7(28 \%)$ & $1(2.44 \%)$ & $8(12.12 \%)$ \\
] $20-40]$ & $16(64 \%)$ & $15(36.59 \%)$ & $31(46.97 \%)$ \\
] $40-60]$ & $1(4 \%)$ & $17(41.46 \%)$ & $18(27.27 \%)$ \\
] $60-80]$ & $1(4 \%)$ & $8(19.51)$ & $9(13.64 \%)$ \\
TOTAL & $25(100 \%)$ & $41(100 \%)$ & $66(100 \%)$ \\
\hline
\end{tabular}

Khi2: $21.59, \mathrm{p}=0.00008$.

Table 2. Status of sickle cell disease and postoperative complications.

\begin{tabular}{cccc}
\hline $\begin{array}{c}\text { whether or not } \\
\text { postoperative } \\
\text { complications. }\end{array}$ & Oui & Sickle cell status \\
\cline { 2 - 4 } & $1(4 \%)$ & Non & Total \\
\hline yes & $24(96 \%)$ & $40(97.56 \%)$ & $2(30.30 \%)$ \\
No & $25(100 \%)$ & $41(100 \%)$ & $64(96.97 \%)$ \\
TOTAL & & $66(100 \%)$ \\
\hline
\end{tabular}

Chi-2 $=0.15, \mathrm{p}=0.703$.

cholecystectomy was retrograde in 21 cases in sickle cell patients and 33 cases in non-sickle cell patients. In 9 cases, tight perivicular adhesions made the intervention difficult for sickle cell patients. They were found in 11 cases in non-sickle cell patients. Seventeen intraoperative accidents occurred globally, including 3 in the sickle cell group and 14 in the non-sickle cell group. These accidents consisted of controlled cystic artery injury $(n=5)$ and perforation of the gallbladder $(n=12)$. The overall average duration of intervention was $55 \mathrm{~min}$. It was less than $55 \mathrm{~min}$ in 13 cases in sickle cell patients and in 22 cases in non-sickle cell patients. The average duration of global anesthesia was $70 \mathrm{~min}$. It was less than 70 min 9 times in sickle cell patients and 15 times in non-sickle cell patients. The occurrence or not of postoperative complications is shown in $\mathrm{Ta}$ ble 2. Two cases of postoperative complications have been identified. 1 case of acute thoracic syndrome in a sickle cell patient and 1 case of biliary peritonitis in a non-sickle cell patient. Mean hospital stay was 3.2 days in sickle cell patients and 3.71 days in non-sickle cell patients. In the postoperative period, 16 sickle cell patients spent at least 24 hours in the intensive care unit, while no non-sickle cell patients were resuscitated. We did not register deaths in the group of non-sickle cell patients. Mortality was $4 \%(\mathrm{n}=1)$ in the sickle cell group. It was a patient who had an acute thoracic syndrome J1 postoperative in intensive care and who died on day 3 postoperatively.

\section{Discussion}

Low sampling due to scarcity is a limitation to this study. Biliary stones are fre- 
quently associated with sickle cell disease. The prevalence of gallstones in homozygous sickle cell patients varies from one country to another: $34 \%$ to $70 \%$ in the United States, $29 \%$ in Jamaica, $4 \%$ to $25 \%$ in Africa and $8 \%$ in Saudi Arabia [5].

Mean age was 25.76 years for sickle cell patients and 45.61 years for non-sickle cell patients $(\mathrm{p}=0.00008)$. This age difference is statistically significant. Ultrasound surveillance in sickle cell patients makes it possible to estimate the onset of vesicular lithiasis from the age of 2 to 4 years with a prevalence that increases with time [6]. About $30 \%$ of patients have gallstone at age 18 [6]. The systematic search for vesicular lithiasis in sickle cell patients at the CRLD may have contributed to the recruitment of young subjects in our study. Mr. Diop in Dakar had an average age of 12.3 years [7]. In the course of its study, which concerned only children, the search for cholelithiasis was either systematic or guided by the existence of painful abdominal symptoms [7].

The female sex is a risk factor because of the hormonal influence (estrogen) which increases the saturation of the bile by stimulating the hepatocyte synthesis of cholesterol. In our study, the frequency of females in both groups was $63.64 \%$, with a sex ratio of 0.57. This frequency is similar to that of European and African studies ranging from $58.97 \%$ to $84.4 \%$ [8] [9] [10]. There was no statistically significant difference in sex between the 2 groups.

No non-sickle cell patients were transfused during our study. Seventy-two percent of sickle cell patients $(n=18)$ were transfused to the CRLD the day before the procedure. This blood transfusion occurred only for SS homozygous sickle cell patients in order to reduce the abnormal hemoglobin (S) to minimize postoperative complications. The reduction of hemoglobin $S$ by transfusion of erythrocyte concentrates or by exchange transfusion reduces the risk of vascular occlusion, reduces hyperviscosity and improves perfusion and oxygenation of distal territories [2]. MESHIKHES, which performed 59.15\% simple transfusion, demonstrated that transfusion for hemoglobin levels below $10 \mathrm{~g} / \mathrm{dl}$ had a preventive effect on postoperative hypoxia [11]. Diop in his study of homozygous Sickle Cell Children SS transfused in $100 \%$ of cases [7]. Soumare recorded a transfusion rate of $60 \%$ in a study that only concerned sickle cell patients and transfused only for hemoglobin levels $<9 \mathrm{~g} / \mathrm{dl}$ or when the patient showed signs of decompensation of his anemia [1].

Our sickle cell patients were all classified ASA II at pre-anesthetic consultation while non-sickle cell patients were ASA I 53.66\% $(\mathrm{n}=22)$ and ASA II 1946.34\% $(\mathrm{n}=19)$.

All our patients were operated under general anesthesia with orotracheal intubation. The same anesthetic process has been found in the literature [1] [7] [8] [12] [13]. Some authors have used locoregional anesthesia under special conditions [14]. In operation, the appearance of the gall bladder appeared normal in $84 \%$ of cases whereas it was either thick-walled or adherent in $51 \%$ of cases of the non-sickle cell group ( $\mathrm{p}=0.009$ ). This difference could be due to the fact that the cholecystectomy was made in sickle cell after the first crisis or most of- 
ten prophylactically. Some authors believe that it seems reasonable to propose laparoscopic cholecystectomy under good conditions before the occurrence of serious complications [3] [12]. For Ka, prophylactic cholecystectomy in homozygous sickle cell disease makes it possible to avoid delay in management related to the confusion between biliary symptomatology and abdominal vaso-occlusive seizures [13]. The presentation of the different anatomical structures and the difficulties of opening Callot's triangle required either retrograde cholecystectomy or anterograde cholecystectomy without a statistically significant difference between the two groups $(p=0.720)$. The average duration of intervention in our study is less than that of Fall, which is 60 minutes [5] $(p=0.046)$. It is not different from that of Diop Ndoye which is $55 \mathrm{~min}(\mathrm{p}=0.065)$ [8]. We did not notice any difference between the two groups with respect to the average duration of intervention. Complications such as biliary peritonitis and acute thoracic syndrome were observed postoperatively. Biliary peritonitis occurred in a non-sickle cell patient on postoperative D8 due to a choledochal wound that was not observed intraoperatively (the reoperation was done by median laparotomy). The case of acute thoracic syndrome occurred on day 1 postoperatively. The patient was taken care of by the resuscitation department and died there on D3 postoperatively. Ka during his study had a case of acute thoracic syndrome which after treatment evolved favorably after 5 days [13]. Fall has had complications such as thoracic syndrome ( 2 cases), vaso-occlusive attacks ( 3 cases) and biliary peritonitis ( 1 case) [5]. Parez found in his patients under laparoscopy a case of biliary peritonitis, a case of right pleural effusion, a case of vaso-occlusive crisis and a case of isolated fever evoking an intercurrent viral infection rather than a surgical complication [12]. The occurrence of acute thoracic syndrome after surgery in sickle cell disease ranges from $6.6 \%$ to $20 \%$ of cases with a mortality of $5 \%$ [13]. Mean hospital stay was not statistically different across groups. It was lower than that of Ka in Senegal (4 days) [13] and G. Bonkoungou in Burkina (5 days) [8].

\section{Conclusion}

The prevalence of sickle cell trait is very high in Mali. The multidisciplinary perioperative management of sickle cell disease means that there is no difference between laparoscopic cholecystectomy carried out in sickle cell and the same technique carried out in non-sickle cell patients. The prevention of serious postoperative complications justifies routine preventive cholecystectomy in any sickle cell patient with non-symptomatic vesicular lithiasis.

\section{Conflicts of Interest}

The authors declare no conflicts of interest regarding the publication of this paper.

\section{References}

[1] Soumaré, L., Sanogo, Z.Z., Koumaré, S., Camara, M., Dicko, H., Touré, B.A., Keïta, 
S., Camara, A., Sacko, O., Koïta, A., Ombotimbé, A. and Sangare, D. (2013) La Cholécystectomie Laparoscopique Chez Le Drépanocytaire. Le Journal de Coelio-Chirurgie, 88, 17-20.

[2] Schoeffler, M. (2008) Anesthesie et Drepanocytose. 15eme Congres Icar, Lyon. https://sofia.medicalistes.fr/spip/IMG/pdf/anesthesie_et_drepanocytose_15e_conres _icar_novembre_2008_dr_m._schoeffler_.pdf

[3] Habibi, A., Bachir, D. and Godeau, B. (2004) Complications aiguës de la drépanocytose. La Revue du Praticien, 54.

[4] Klimek, P., Kesslera, U., Schiblib, S., Bergera, S. and Zachariou, Z. (2009) Lithiases biliaires chez les enfants. Forum Médical Suisse, 9, 246-250.

https://doi.org/10.4414/fms.2009.06781

[5] Fall, B., Sagna, A., Diop, P.S., Faye, E.A.B., Diagne, I. and Dia, A. (2003) La cholécystectomie laparoscopique dans la drépanocytose. Annales de Chirurgie, 128, 702-705. https://doi.org/10.1016/j.anchir.2003.10.013

[6] Recommandation de bonne pratique (2005) Prise en charge de la drépanocytose chez l'enfant adolescent. HAS Service des recommandations professionnelles, 1-106.

[7] Diop Ndoye, M., Diao Bah, M., Ndiaye Pape, L., Diouf, E., Kane, O., Beye, M., Fall, B. and KA-Sall, B. (2008) Prise en charge de la cholécystectomie par voie laparoscopique chez l'enfant drépanocytaire homozygote. Archives de Pédiatrie, 15, 1393-1397. https://doi.org/10.1016/j.arcped.2008.06.012

[8] Bonkoungou, G., Sanou, A., Kabore, F., Sam, T., Bonkoungou, Z., Zida, M., Traore, S. and Sano, D. (2009) La cholécystectomie laparoscopique au burkina faso: A propos de 32 CAS. Le Journal de Coelio-Chirurgie, 71, 57-60.

[9] Arnaud, J.P., Casa, C., Bruant, P., Pousset, J.P., Georgeac, C., Bergamaschi, R. and Ronceray, J. (1993) Cholécystectomie par cœlioscopie: A propos de 126 cas. Annales de Chirurgie, 47, 307-310.

[10] Guillaume, P. and Persiani, R. (2003) Le risque de plaies biliaires au cours de la Cholécystectomie par laparoscopie. Journal de Chirurgie, 141, 343-353. https://doi.org/10.1016/S0021-7697(04)95358-6

[11] Meshikhes, A.W., Al-abkari, H.A., Al-Faraj, A.A., Al-Dhurais, S.A., Saif, A.L.-O., et al. (1998) La sécurité de la cholécystectomie laparoscopique dans la drépanocytose: Une mise à jour. Arabie Saoudite, 18, 12-14. https://doi.org/10.5144/0256-4947.1998.12

[12] Parez, N., Quinet, B., Batut, S., Grimpel, E., Larroquet, M., Audry, G. and Begue, P. (2001) Lithiase biliaire chez l'enfant drépanocytaire: Expérience d'un hôpital pédiatrique parisien. Archives de Pédiatrie, 8, 1045-1049. https://doi.org/10.1016/S0929-693X(01)00581-4

[13] Kâ, O., Diagne, I., Bâ, P.A., Cissé, M., Kâ, I., Dieng, M., Dia, A. and Touré, C.T. (2010) Cholecystectomie prophylactique laparoscopique pour lithiase vesiculaire chez l'enfant drepanocytaire. Le Journal de Coelio-Chirurgie, 76, 51-54.

[14] Baş, S.Ş. and Özlü, O. (2012) Epidural Anesthesia for Laparoscopic Cholecystectomy in a Patient with Sickle Cell Anemia, Beta Thalassemia, and Crohn's Disease-A Case Report. Korean Journal of Anesthesiology, 63, 357-359.

https://doi.org/10.4097/kjae.2012.63.4.357 